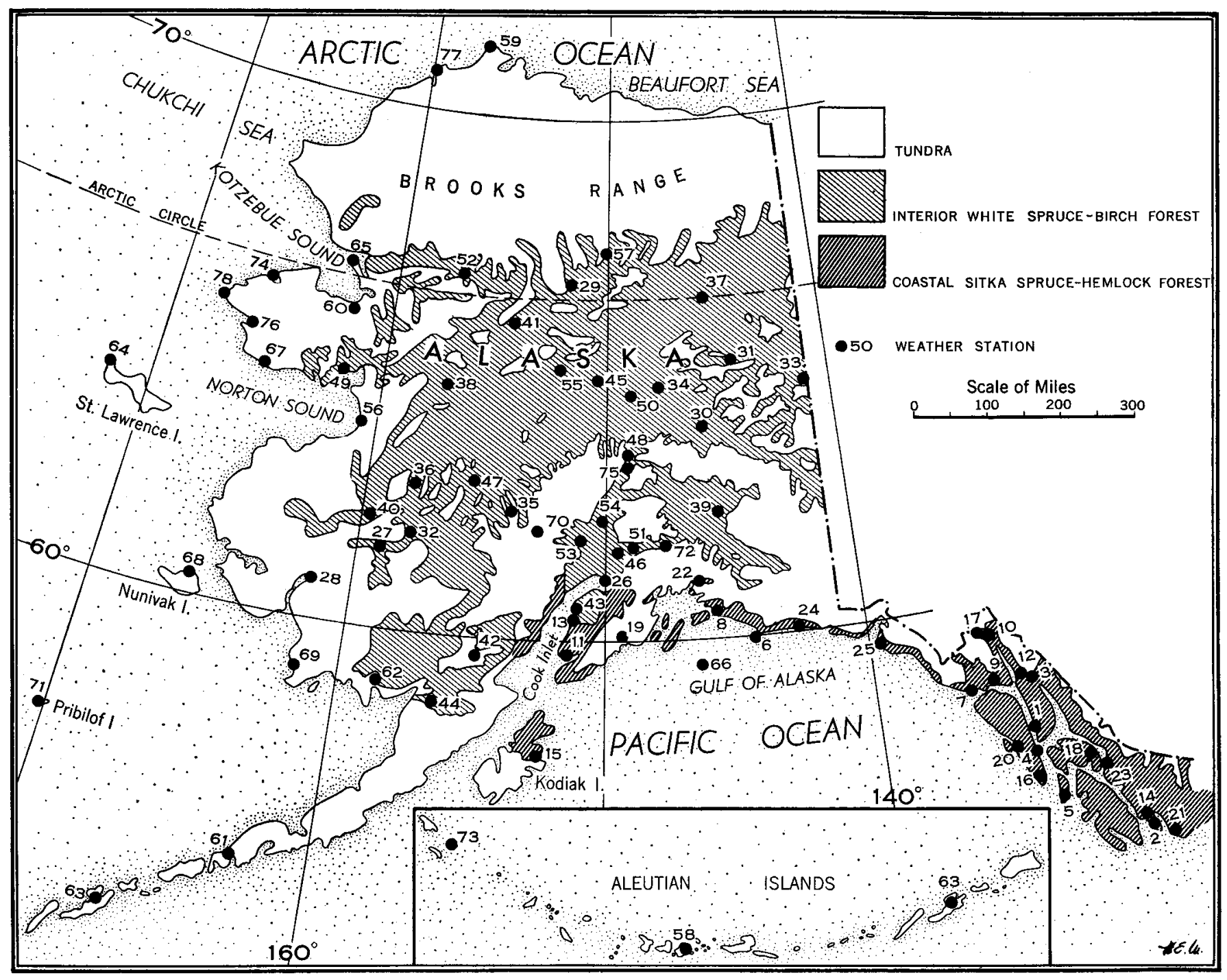

Fig. 1. Index map of Alaska 


\title{
SOME CHARACTERISTICS OF THE CLIMATE IN FOREST AND TUNDRA REGIONS IN ALASKA*
}

\author{
David M. Hopkins $\dagger$
}

$\mathrm{T}$

HE present-day vegetation of Alaska consists of three major types: the coastal Sitka spruce-hemlock forest of southeastern and south-central Alaska; the interior white spruce-birch forest of central Alaska; and the treeless tundra of western and northern Alaska (Sigafoos 1958). All three vegetation types are represented by assemblages of fossil plant remains found in different strata of late Cenozoic age in western Alaska (Hopkins and Benninghoff 1953). A desire to assess the palaeoclimatic significance of these fossil plant assemblages led to the results that are presented here.

The coastal forest extends a few tens of miles inland along the coast of southeastern and southern Alaska westward to Cook Inlet and northeastern Kodiak Island (Fig. 1); the interior forest is distributed through most of central Alaska north of the coastal mountains and south of the Brooks Range; and the tundra is found beyond the continental limits of forest in central and western Alaska and in highland areas above the altitudinal limits of forest in central and southern Alaska.

Both forest types contain several species of trees in addition to those employed here to characterize them (Sigafoos 1958), and the tundra is a mosaic of many different sorts of vegetation, some of which are limited to either southern or northern tundra regions (Griggs 1936, Hanson 1953, Britton 1957).

The detailed boundary between forest and tundra is intricate and is determined by small differences in the character of the soil, drainage conditions, intensity of frost action, and perhaps microclimate (Sigafoos 1953). The detailed boundary between coastal and interior forest no doubt reflects similar minor variations in environmental conditions. In a few places in Alaska the boundaries between major vegetation units appear to be shifting actively and rapidly in response to recent small climatic changes (Griggs 1934). However, the data presented here suggest that in much of Alaska the gross boundaries between the three major vegetation types reflect regional or altitudinal differences in the annual temperature regime.

* Publication authorized by the Director, U. S. Geological Survey.

$\dagger$ U. S. Geological Survey, Menlo Park, Calif. 
It has long been recognized that the gross boundary between forest and tundra is related to some threshold value for summer warmth. Köppen (1936) and many others have pointed out a fair world-wide correspondence between the northern limit of trees and the $50^{\circ} \mathrm{F}$. isotherm for the warmest month; Nordenskjöld's Arctic Limit (Nordenskjöld and Mecking 1928), which takes the mean temperature of the coldest month into account, coincides with the northern tree line about equally well; but both lines diverge grossly from the forest-tundra boundary in western Alaska (see Hare 1955, Fig. 21).

The relationships between cumulative summer warmth and the distributions of both individual species and larger vegetational units have been analyzed by many investigators concerned primarily with more temperate regions (cf. Merriam 1894, Livingston and Shreve 1921). Hare (1950) reviews the numerous studies that have indicated that mid-summer temperatures control the growth rates of the coniferous trees composing the boreal forest and shows that there is a close correspondence in northeastern Canada between zonal forest divisions and Thornthwaite's thermal efficiency index, an accumulating logarithmic function of monthly mean temperatures (Thornthwaite 1948).

This paper attempts to establish a more faithful correspondence between a temperature parameter and the forest-tundra boundary in Alaska using summations of cumulative summer warmth, and it attempts to characterize the differences between the temperature regimes of the region of the interior white spruce-white birch forest and the region of the coastal Sitka spruce-hemlock forest. The temperature records for 78 Alaskan weather stations that have been in operation for 10 years or more furnished the data for the study (Table 1).

After several other approaches had failed a good correspondence was discovered between the vegetation at the station and the number of degreedays above $50^{\circ} \mathrm{F}$. on one hand and the mean temperature of the coldest month on the other (Fig. 2). Degree days are normally computed by calculating the sum of the departure of mean daily temperatures from an adopted reference temperature during a chosen interval. For this study the number of degree-days above $50^{\circ} \mathrm{F}$. was approximated by multiplying the amount by which the mean temperature of the warmer months exceeded $50^{\circ} \mathrm{F}$. times the number of days in the warm months. For example, a station reporting a mean July temperature of $55^{\circ} \mathrm{F}$., a mean August temperature of $51^{\circ} \mathrm{F}$. and mean temperatures below $50^{\circ} \mathrm{F}$. for the other 10 months would be computed as follows:

$$
5 \times 31+1 \times 31=186 \text { degree-days above } 50^{\circ} \mathrm{F} \text {. }
$$

All weather stations in either the coastal or the interior forest record more than 130 degree-days above $50^{\circ} \mathrm{F}$., and nearly all weather stations beyond or above the limit of forest record less than 130 degree-days above $50^{\circ} \mathrm{F}$. (Fig. 2). Similar but less sharply defined results were obtained by comparing the number of degree-days above $45^{\circ} \mathrm{F}$. with the vegetation at the station, but no correspondence was found between the number of 
degree-days above $40^{\circ} \mathrm{F}$. or $32^{\circ} \mathrm{F}$. and the local vegetation. The coastal Sitka spruce-hemlock forest and the interior white spruce-birch forest evidently have similar summer heat requirements; neither forest is found in areas having less than a critical amount of heat above a threshold value in the high 40's ( ${ }^{\circ} \mathrm{F}$.).

Several tundra stations in southern and southwestern Alaska report as much summer warmth as do stations in forested regions elsewhere. Treeless Middleton Island and Dutch Harbor (66 and 63 on Figs. 1 and 2)

Table 1. Temperature data for 78 Alaskan weather stations that have been in operation 10 years or more (U.S. Weather Bureau 1947-1957)

\begin{tabular}{|c|c|c|c|c|c|c|c|}
\hline Station & $\begin{array}{l}\text { Years of } \\
\text { record }\end{array}$ & $\begin{array}{c}\text { Degree- } \\
\text { days } \\
\text { above } \\
50^{\circ} \mathrm{F}\end{array}$ & $\begin{array}{c}\text { Temp. } \\
\left({ }^{\circ} \mathrm{F} .\right) \\
\text { of coldest } \\
\text { month }\end{array}$ & Station & $\begin{array}{l}\text { Years of } \\
\text { record }\end{array}$ & $\begin{array}{c}\text { Degree- } \\
\text { days } \\
\text { above } \\
50^{\circ} \mathrm{F} .\end{array}$ & $\begin{array}{l}\text { Temp. } \\
\left({ }^{\circ} \mathrm{F} .\right) \\
\text { of coldest } \\
\text { month }\end{array}$ \\
\hline
\end{tabular}

Coastal Sitka spruce-hemlock forest

$\begin{array}{llll}\text { 1. Angoon } & 33 & 302 & 29.3 \\ \text { 2. Annette } & 15 & 581 & 34.6 \\ \text { 3. Annex Creek } & 31 & 363 & 23.4 \\ \text { 4. Baranof } & 15 & 476 & 29.2 \\ \text { 5. Cape Decision } & 10 & 228 & 33.9 \\ \text { 6. Cape St. Elias } & 15 & 431 & 33.1 \\ \text { 7. Cape Spencer } & 19 & 161 & 32.2 \\ \text { 8. Cordova WB } & 14 & 207 & 25.0 \\ \text { 9. Gustavus } & 18 & 351 & 27.1 \\ \text { 10. Haines CAA } & 29 & 590 & 23.2 \\ \text { 11. Homer CAA } & 20 & 171 & 23.2 \\ \text { 12. Juneau WB } & 15 & 384 & 26.2 \\ \text { 13. Kasilof } & 14 & 279 & 13.4 \\ \text { 14. Ketchikan } & 45 & 556 & 35.3 \\ \text { 15. Kodiak } & 49 & 276 & 30.2 \\ \text { 16. Little Pt. Walter } & 20 & 382 & 33.1 \\ \text { 17. Moose Valley } & 10 & \mathbf{5 2 8} & 10.0 \\ \text { 18. Petersburg } & 24 & 470 & 28.6 \\ \text { 19. Seward } & \mathbf{3 4} & 401 & 24.2 \\ \text { 20. Sitka Magnetic } & \mathbf{7 2} & 488 & 33.3 \\ \text { 21. Tree Point } & 18 & 656 & 34.8 \\ \text { 22. Valdez } & \mathbf{3 8} & \mathbf{1 4 9} & \mathbf{1 9 . 2} \\ \text { 23. Wrangell } & 29 & 659 & 30.2 \\ \text { 24. Yakataga } & 13 & 176 & 27.0 \\ \text { 25. Yakutat } & 11 & 171 & 26.5\end{array}$

Interior white spruce-birch forest

$\begin{array}{lllr}\text { 26. Anchorage } & 35 & 511 & 13.0 \\ \text { 27. Aniak } & 13 & 328 & -1.9 \\ \text { 28. Bethel } & \mathbf{3 4} & 301 & 6.8 \\ \text { 29. Bettles } & 14 & 411 & -12.5 \\ \text { 30. Big Delta } & 14 & 613 & -2.1 \\ \text { 31. Circle Hot Sprs. } & 16 & 668 & -13.1 \\ \text { 32. Crooked Creek } & 11 & 485 & 0.4 \\ \text { 33. Eagle } & 37 & 629 & -12.4 \\ \text { 34. Fairbanks WB } & 28 & 791 & -9.8 \\ \text { 35. Farewell } & 13 & 192 & \mathbf{1 . 6} \\ \text { 36. Flat } & 21 & 433 & -2.0 \\ \text { 37. Fort Yukon } & 30 & 776 & -19.1 \\ \text { 38. Galena } & 14 & 720 & -9.3 \\ \text { 39. Gulkana } & 15 & 406 & -5.9\end{array}$

3.0 $-1.9$

-1.9
6.8

$-2.1$

13.1

0.4

$-9.8$

1.6

$-2.0$

-9.3
-5.9
Interior white spruce-birch forest (cont.)

40. Holy Cross $\quad 44 \quad 506 \quad 2.2$

41. Hughes $\quad 13 \quad 577 \quad-8.8$

42. Iliamna $\quad 15 \quad 266 \quad 14.1$

43. Kenai CAA $\quad 18 \quad 214 \quad 11.5$

44. King Salmon $\quad 24 \quad 328 \quad 14.1$

45. Manley Hot Sprs. $23 \quad 603 \quad-10.1$

$\begin{array}{llll}\text { 46. Matanuska } & 33 & 563 & 13.1\end{array}$

47. McGrath $\quad 16 \quad 550 \quad-8.7$

48. McKinley Park $31 \quad 245 \quad 4.6$

49. Moses Point $15 \quad 133 \quad-0.5$

$\begin{array}{llll}\text { 50. Nenana } & 28 & 740 & -8.0\end{array}$

51. Palmer 1N $\quad 15 \quad 513 \quad 13.4$

52. Shungnak $\quad 10 \quad 396 \quad-4.6$

53. Skwentna $\quad 16 \quad 580 \quad 5.9$

$\begin{array}{llll}\text { 54. Talkeetna } & 36 & 497 & 8.5\end{array}$

55. Tanana $\quad 47 \quad 554 \quad-9.5$

56. Unalakleet $\quad 15 \quad 178 \quad 2.5$

$\begin{array}{llll}\text { 57. Wiseman } & 17 & 413 & -9.9\end{array}$

Tundra

58. Adak

59. Barrow

60. Candle

61. Cold Bay

62. Dillingham

63. Dutch Harbor

64. Gambell

65. Kotzebue

66. Middleton Island

67. Nome WB

68. Nunivak

69. Platinum

70. Puntilla

71. St. Paul

72. Sheep Mountain

73. Shemya

74. Shishmaref

75. Summit

76. Teller

77. Wainwright

78. Wales

$\begin{array}{rrr}14 & 40 & 32.8 \\ 15 & 0 & -17.9 \\ 21 & 90 & -9.4 \\ 13 & 65 & 28.4 \\ 16 & 340 & 15.9 \\ 28 & 164 & 31.8 \\ 17 & 0 & 3.4 \\ 15 & 103 & -21.0 \\ 15 & 213 & 33.7 \\ 41 & 0 & 5.6 \\ 12 & 0 & 10.9 \\ 13 & 93 & 14.6 \\ 10 & 65 & 3.4 \\ 38 & 0 & 23.8 \\ 15 & 129 & 7.2 \\ 10 & 0 & 30.9 \\ 24 & 0 & -4.3 \\ 15 & 74 & 2.3 \\ 15 & 31 & -0.3 \\ 11 & 0 & -17.9 \\ 13 & 0 & 0.8\end{array}$




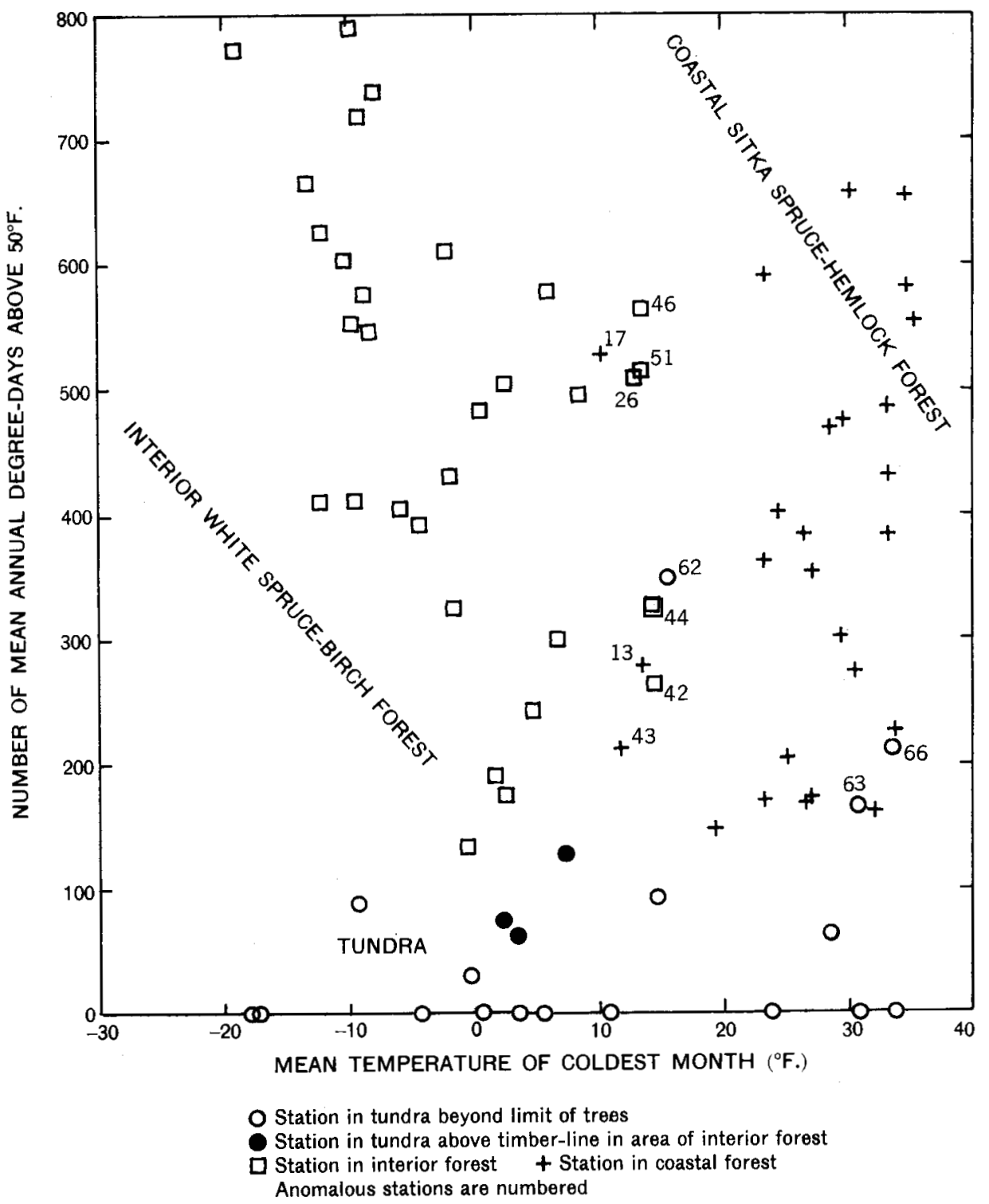

Fig. 2. Temperature conditions compared with vegetation at 77 Alaskan weather stations. Anomalous stations: 13, Kasilof; 17, Moose Valley; 26, Anchorage; 42, Iliamna; 43, Kenai; 44, King Salmon; 46, Matanuska; 51, Palmer; 62, Dillingham; 63, Dutch Harbour; 66, Middleton Island.

Note added in proof: The symbol for Dutch Harbor, numbered 63, has been misplaced and should be farther to the right to indicate that the temperature of the coldest month is $31.8^{\circ} \mathrm{F}$. 
are remote from sources of seed, but Sitka spruce has been successfully introduced on Unalaska Island near Dutch Harbor (Griggs 1936, p. 413). The other tundra stations having exceptionally warm summers (Dillingham - 62 on Figs. 1 and 2 - and several weather stations on Kodiak Island that were occupied too briefly to be included in this study) lie in a region in which both the coastal and the interior forest are reported to be vigorously expanding into the tundra (Griggs 1934).

The climates of the areas of the coastal forest and of the interior forest differ chiefly in the severity of the winters. Nearly all weather stations within the interior forest report at least one winter month during which the mean temperature is lower than $10^{\circ} \mathrm{F}$., and nearly all stations in the coastal forest report no winter month having a mean temperature as low as $15^{\circ} \mathrm{F}$. Tundra appears indifferently in areas having mild winters and in areas having cold winters.

Three stations in the coastal forest near the boundary with the interior forest (Kasilof, 13; Kenai, 43; and Moose Valley, 17, on Figs. 1 and 2) and five stations in the southern part of the interior forest (Matanuska, 46; Palmer, 51, Anchorage, 26, King Salmon, 44; and Iliamna, 42) report coldest winter months having temperatures between $10^{\circ} \mathrm{F}$. and $15^{\circ} \mathrm{F}$. The stations clustered about the head of Cook Inlet lie in a transitional zone in which the two forest types intergrade; along the line on the map separating the two types, the forest is a mixture of Sitka spruce, white spruce, and hybrids between Sitka and white spruce (Sigafoos 1958, p. 177; Benninghoff, written communication 1958). The other three stations lie in areas where the interior and coastal forests are isolated from one another by mountain ranges bearing only tundra vegetation, so that opportunities for mixing and hybridization are at a minimum.

Assemblages of fossil plants furnish part of the evidence on which palaeoclimatic interpretations must rely. Attempts to reconstruct ancient climates using the evidence of fossil plants rest on the assumption that the ancient forms had nearly the same ecological requirements as their living representatives. The reliability of the assumption improves with increasing size of the fossil flora, with increasingly close taxonomic relationship between the individual fossil forms and their living representatives, and with decreasing time separation between the age of the fossil flora and its living equivalent. Unfortunately, fossil plant assemblages generally represent only a small part of the plant community from which they were derived, and commonly the identity of the individual forms with living forms cannot be proved; but this difficulty is minimized for many fossil floras by the availability of collateral pedologic, stratigraphic, or geomorphic evidence concerning the nature of the climate in which the floras lived.

It is reasonable to assume that the assemblages of species making up the major vegetation types in Alaska have had approximately the same climatic requirements during much of late Cenozoic time, and that fossil assemblages clearly assignable to these major vegetation types may be 
used as evidence in palaeoclimatic reconstructions. Fossil remains of coastal Sitka spruce-hemlock forest suggest past periods of warm summers and mild winters; fossil remains of interior white spruce-birch forest suggest past periods of warm summers and severe winters; and fossil remains of tundra vegetation suggest past periods of cold summers and either mild or severe winters.

I have benefited greatly by discussing the ideas presented here with R. S. Sigafoos and W. S. Benninghoff.

\section{References}

Britton, M. E. 1957. Vegetation of the arctic tundra. 18th Biological Colloquium. Oregon State College, pp. 26-61.

Griggs, R. F. 1934. The edge of the forest in Alaska and the reasons for its position. Ecology 15: 81-96.

1936. The vegetation of the Katmai district. Ecology 17:380-417.

Hanson, H. C. 1953. Vegetation types in northwestern Alaska and comparisons with communities in other arctic regions. Ecology 34:111-40.

Hare, F. K. 1950. Climate and zonal divisions of the boreal forest formation in eastern Canada. Geog. Rev. 40:615-35.

1955. Weather and climate. In Geography of the Northlands, ed. by G. H. Kimble and D. Good, pp. 58-83. New York: Am. Geog. Soc. and Wiley and Sons.

Hopkins, D. M. and W. S. Benninghoff. 1953. Evidence of a very warm Pleistocene interglacial interval on Seward Peninsula, Alaska. Bull. Geol. Soc. Am. 64:1435-6 (Abstr.).

Köppen, W. 1936. Das geographische System der Klimate. In Handbuch der Klimatologie, ed. by W. Köppen and R. Geiger, Vol. 1. Berlin: Gebrüder Bornträger.

Livingston, B. E. and F. Shreve. 1921. The distribution of vegetation in the United States, as related to climatic conditions. Carnegie Inst. Wash. Publ. 284, 590 pp.

Merriam, C. H. 1894. Laws of temperature control of the geographic distribution of terrestrial animals and plants. Natl. Geog. Mag. 6:229-38.

Nordenskjöld, $O$. and L. Mecking. 1928. The geography of the polar regions. Am. Geog. Soc. Spec. Publ. 8, 359 pp.

Sigafoos, R. S. 1953. Characteristics of spruce forest on Seward Peninsula, Alaska. Bull. Ecol. Soc. Am. 34:91 (Abstr.).

1958. Vegetation of northwestern North America, as an aid in interpretation of geologic data. U. S. Geol. Surv. Bull 1061-E: 165-85.

Thornthwaite, C. W. 1948. An approach to a rational classification of climate. Geog. Rev. 38: 55-94.

U. S. Weather Bureau. 1947-57. Climatological data, Alaska, annual summary. Vols. $33-43$. 